\title{
IMPLEMENTASI TRANSFER LEARNING PADA CONVOLUTIONAL NEURAL NETWORK UNTUK DIAGNOSIS COVID-19 DAN PNEUMONIA PADA CITRA X-RAY
}

\author{
Alexander Eric Wijaya ${ }^{1}$, Windra Swastika ${ }^{2}$, Oesman Hendra Kelana ${ }^{3}$ \\ Program Studi Teknik Informatika, Universitas Ma Chung \\ Email : $311710001 @$ student.machung.ac.id, windra.swastika@machung.ac.id, \\ oesman.hendra@machung.ac.id
}

\begin{abstract}
Abstrak
COVID-19 menjadi salah satu masalah yang besar bagi banyak negara di dunia sejak tahun 2020. COVID-19 dan Pneumonia memiliki kemiripan dalam hal gejala seperti batuk dan sesak napas. Upaya diagnosis COVID-19 dan Pneumonia dilakukan dengan pemeriksaan laboratorium dan juga rontgen dada. Citra hasil x-ray dada pasien COVID-19 memiliki kesamaan dengan hasil $\mathrm{x}$-ray pasien Pneumonia tetapi ahli radiologi berhasil menemukan bahwa terdapat perbedaan antara citra x-ray dada penderita COVID-19 dengan citra x-ray dada pasien Pneumonia dimana terdapat pola seperti kaca yang ditumbuk pada hasil citra X-ray penderita virus Corona.Diagnosis pada citra $\mathrm{x}$-ray dada pasien menggunakan model Deep Learning. Pada penelitian ini juga akan membandingkan performa model Xception menggunakan Transfer Learning dengan performa model Xception tanpa Transfer Learning. Terdapat 4 eksperimen konfigurasi pada model Xception tanpa Transfer yaitu konfigurasi pelatihan layer base model, pelatihan base model, pelatihan custom head model, dan pelatihan pada layer base model serta custom head model. Terdapat 2 eksperimen menggunakan model Resnet50 dan VGG16 tanpa Transfer Learning. Model Xception menggunakan Transfer Learning memiliki performa lebih baik daripada model Xception tanpa Transfer Learning. Keempat eksperimen model Xception tanpa Transfer Learning dan kedua eksperimen dengan model Resnet serta VGG16 memiliki akurasi diatas 85\%. Namun keenam model tanpa Transfer Learning tersebut tidak mampu mengenali Pneumonia pada citra X-ray dada pasien.
\end{abstract}

Kata kunci: Transfer Learning, Pneumonia, COVID-19, Virus Corona, CNN, X-Ray, Deep Learning

Abstract
COVID-19 has become one of the big problems for countries in the world since 2020. COVID-19 and Pneumonia have many symptoms such as coughing and shortness of breath. Efforts to diagnose COVID-19 and Pneumonia are carried out by laboratory examinations and also chest $X$-rays. The chest $x$ ray images of COVID-19 patients have similarities with the $x$ ray results of Pneumonia patients, but radiologists managed to find that there are differences between the chest $x$-ray images of COVID-19 patients and the chest $x$-ray images of Pneumonia patients where there is a glass-like pattern. pounded on X-ray images of patients with the Corona virus.

Diagnosis is on the patient's chest $x$-ray image using the Deep Learning model. This study will also compare the performance of the Xception model using Transfer Learning with the performance of the Xception model without Transfer Learning. There are 4 configuration experiments on the Xception model without Transfer, namely training on the configuration of the base model layer, training on the custom head model, and training on the base model layer and custom head model. There are 2 experiments using Resnet50 and VGG16 models without Transfer Learning.

The Xception model using Transfer Learning has better performance than the Xception model without Transfer Learning. The four Xception model experiments without Transfer Learning and the second experiment with the Resnet and VGG16 models had accuracy above $85 \%$. However, the model without Transfer Learning was not able to recognize Pneumonia on the patient's chest $x$-ray image.

Keywords: Transfer Learning, Pneumonia, COVID-19, virus Corona, CNN, X-Ray, Deep Learning

\section{PENDAHULUAN}

Bangsa-bangsa di seluruh dunia dihadapkan pada masalah pandemi Corona sejak awal tahun 2020. Pandemi virus ini telah menyebar dan menjangkiti lebih dari 200 negara yang ada di seluruh dunia pada awal bulan Maret 2021. Pada website resmi Worldometer, tercatat bahwa pada 2 Agustus 2021, kasus COVID-19 hampir mencapai 200 juta kasus dan lebih dari 4 juta kasus meninggal dunia (Worldometer, 2021). COVID-19 dan Pneumonia memiliki kemiripan dalam hal gejala seperti batuk dan sesak nafas. Diagnosis dapat dilakukan dengan cara pemeriksaan lab, tes darah, ataupun menggunakan rontgen dada pasien. Seorang ahli radiologi Paras Lakhani mengatakan bahwa terdapat citra seperti kaca yang ditumbuk pada pasien dan citra itu mewakili cairan di paru-paru sebagai akibat dari virus COVID-19 (Fahrani, 2020).

Pada citra X-ray dada pasien COVID-19, terdapat Ground Glass Opacity yakni rongga udara di paru-paru terisi oleh semacam cairan.. Di sisi lain, citra x-ray dada pasien Pneumonia kebanyakan masih didapati batas-batas pada paru-paru dan juga sedikitnya Ground Glass Opacity atau bahkan tidak ada GGO sama sekali pada citra x-ray. Model $\mathrm{CNN}$ akan digunakan untuk melakukan diagnosis pada citra X-ray dada pasien dengan mengimplementasikan metode Transfer Learning. Pada penelitian ini juga akan membandingkan perforna model yang menggunakan metode Transfer Learning dan performa model non Transfer Learning untuk melihat pengaruh metode Transfer Learning pada model CNN. 


\subsection{COVID-19}

\section{TINJAUAN PUSTAKA}

COVID-19 adalah penyakit yang disebabkan oleh virus corona, virus ini erat kaitannya dengan Severe Acute Respitatory Syndrom (SARS). COVID-19 (coronavirus disease 2019) merupakan penyakit baru yang disebabkan oleh virus dari golongan coronavirus. Gejala klinis yang dapat dilihat pada orang-orang yang terjangkit COVID-19 antara lain demam hingga suhu tubuh di atas 38 derajat Celcius, batuk, sesak napas, sakit kepala, mual, myalgia (nyeri otot), dan nyeri abdomen (Handayani et al., 2020).

Pada kasus penderita COVID-19 yang parah dapat menyebabkan komplikasi yang serius. Komplikasi tersebut antara lain gagal napas akut, pneumonia, gagal jantung akut, gagal hati akut, infeksi sekunder pada organ lain, gangguan pembekuan darah, syok septik bahkan hingga berujung pada kematian. Syok septik merupakan salah satu kondisi kegawatdaruratan yang disebabkan oleh kondisi sepsis, yaitu peradangan di seluruh tubuh akibat infeksi. Syok sepsis ditandai dengan kegagalan fungsi sirkulasi akibat infeksi yang berlanjut.Sebelum mengalami hal-hal tersebut, ada baiknya melakukan diagnosis dengan metode rapid test, tes PCR, CT scan atau rontgen dada, ataupun tes darah secara lengkap (Alodokter, 2021).

\subsection{Pneumonia}

Pneumonia merupakan penyakit peradangan paru-paru dengan gejala-gejala beruupa panas tinggi disertai dengan batuk berdahak, napas cepat, sesak napas, serta gejala umum lainnya seperti sakit kepala, gelisah, dan nafsu makan berkurang (Irawan et al., 2019). Penyebab Pneumonia antara lain akibat adanya infeksi dari bakteri (seperti Streptococcus pneumoniae), virus, dan atau jamur yang menyerang orang dengan gangguan sistem imun.

Penyakit Pneumonia tergolong penyakit berbahaya karena dapat menimbulkan berbagai macam komplikasi antara lain bakterimia, luka pada organ paru-paru, efusi pleura, dan infeksi pada salah satu bagian jantung. Hal ini terjadi ketika bakteri penyebab infeksi masuk ke dalam darah sehingga menyebabkan penurunan tekanan darah, peradangan di dalam darah, bahkan dalam beberapa kasus mengakibatkan kegagalan organ.

\subsection{Transfer Learning}

Transfer Learning merupakan metode ataupun teknik yang menggunakan model pre-trained (sudah dilatih terhadap suatu dataset) untuk menyelesaikan permasalahan lain yang serupa dengan cara menggunakannya sebagai starting point, lalu memodifikasi dan mengupdate parameternya sehingga sesuai dengan dataset kasus permasalahan yang baru (Sena, 2018). Contoh dari Transfer Learning yaitu menggunakan model pre-trained yang dilatih untuk mengenali mobil, lalu model tersebut digunakan untuk mengenali truk.

Pada gambar 1 mengenai perbedaan antara Machine Learning tradisional dan Transfer Learning dapat dilihat perbedaan yang mencolok pada Transfer Learning dimana terdapat proses knowledge transfer antara model A yang merupakan model pre-trained dan model $\mathrm{B}$ yang akan menjadi model baru untuk kasus yang baru juga. Transfer Learning membutuhkan model pre-trained yang akan digunakan lalu model itu akan dimodifikasi dan dilakukan fine-tunning sesuai dengan kasus baru yang akan diteliti.

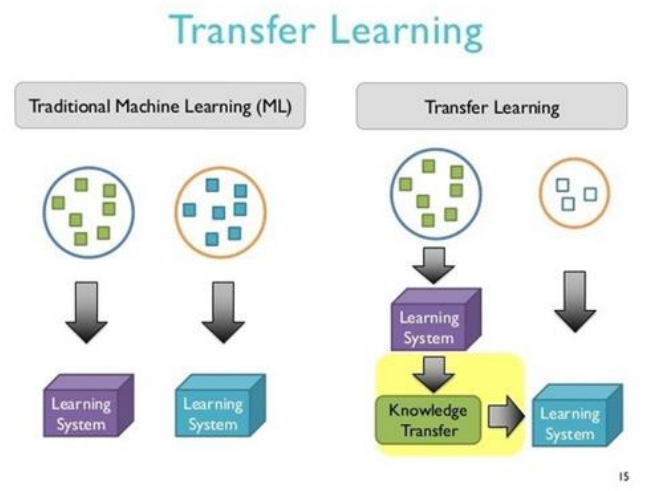

Gambar 1. Transfer Learning

Worklflow atau alur kerja yang paling umum untuk menerapkan transfer learning yaitu dengan cara sebagai berikut. Pertama yaitu dengan cara mengambil lapisanlapisan (layers) dari model yang telah dilatih sebelumnya. Kedua, yaitu dengan cara melakukan pembekuan (freeze) pada lapisan model dengan tujuan untuk menghindari hilangnya informasi pada saat training berlangsung. Ketiga, yaitu dengan cara menambahkan beberapa lapisan (layers) baru di atas lapisan yang dibekukan sehingga model akan belajar mengubah fitur lama menjadi kemampuan prediksi pada dataset yang baru. Cara yang terakhir yaitu melatih layer baru pada dataset.

\subsection{Deep Learning}

Deep Learning adalah cabang ilmu dari Machine Learning yang terinspirasi dari kortex manusia. Deep Learning menerapkan jaringan saraf buatan yang memiliki banyak layer (Santoso \& Ariyanto, n.d.). Deep Learning merupakan salah satu jenis algoritma jaringan saraf tiruan yang menggunakan metadata sebagai input dan mengolah input tersebut menggunakan hidden layer (lapisan tersembunyi). Lapisan tersembunyi berfungsi untuk melatih fitur-fitur berdasarkan nilai output dari jaringan sebelumnya. Proses penghitungan tersebut dilakukan hingga menghasilkan suatu nilai output. Algoritma Deep Learning juga dapat melakukan ekstraksi secara otomatis, hal ini berarti algoritmanya dapat memilih fitur-fitur yang relevan dengan masalah yang akan dipecahkan.

Feature Engineering merupakan salah satu fitur utama dari Deep Learning untuk mempermudah model dalam membedakan kelas. Terdapat algoritma yang dapat digunakan untuk menemukan pola umum yang penting dalam membedakan kelas yaitu metode CNN (Convolutional Neural Network). CNN merupakan salah satu jenis Neural Network yang biasanya digunakan dalam pengolahan data berupa gambar. 
CNN termasuk ke dalam jenis Deep Neural Network dan sering digunakan dalam data-data citra (Peryanto et al., 2019). Convolutional Neural Network (CNN) adalah metode hasil pengembangan dari metode Multi Layer Perceptron (MLP) yang digunakan untuk mengolah data dua dimensi. Konsep CNN secara garis besarnya memiliki banyak kesamaan dengan MLP secara umum.

Multi Layer Perceptron menggunakan metode supervised learning dan tahapannya menggunakan teknik feed forward neural network. Model ini mempunyai dua fase dalam trainingnya yaitu fase forward dan fase backward. MLP bekerja dengan menerima inputan pada layer input yang akan diolah dan dilanjutkan ke masing-masing bagian hidden layer hingga sampai pada output layer. Setelah mendapatkan hasil nilai output, nilai output akan dibandingkan dengan nilai target yang ditentukan. Apabila nilai output tidak sesuai dengan nilai target maka akan dijalankan proses fase backward dan melakukan update pada nilai bobot. Hal ini dilakukan terus menerus hingga mendapatkan nilai output yang diinginkan ataupun dilakukan hingga jumlah iterasi tertentu. Gambar 2 berikut adalah Arsitektur Multi Layer Perceptron secara umum dan sederhana.

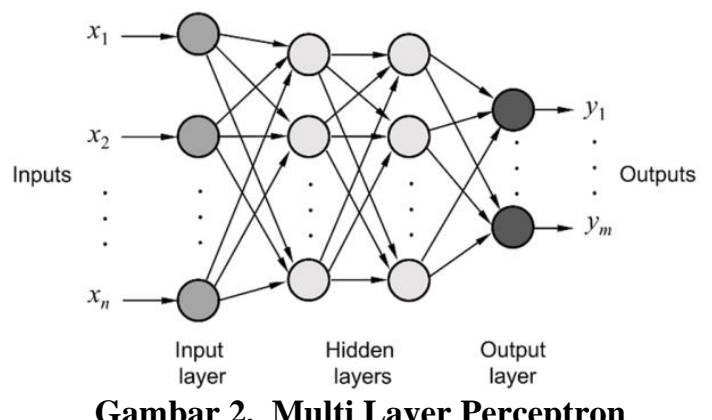

Gambar 2. Multi Layer Perceptron

\subsection{Convolutional Neural Network}

Convolutional Neural Network (CNN) adalah pengembangan dari Multilayer Perceptron (MLP) yang didesain untuk mengolah data dua dimensi. CNN termasuk dalam jenis Deep Neural Network karena kedalaman jaringan yang tinggi. CNN memiliki beberapa kesamaan yang mirip dengan MLP. Walaupun CNN memiliki kesamaan konsep dengan MLP tetapi terdapat sedikit perbedaan yang mencolok yaitu bahwa dalam CNN setiap neuron direpresentasikan dengan bentuk dua dimensi. Hal ini berbeda jauh dengan MLP dimana setiap neuronnya hanya dalam bentuk satu dimensi. Gambar 3 adalah arsitektur CNN secara umum.

Pada tahap Feature Learning, terdapat layer-layer yang digunakan untuk melakukan translasi input menjadi fiturfitur berdasarkan ciri inputan yang diterima. Pada convolutional layer ini menggunakan filter dengan nilai tertentu ataupun random. Pada setiap posisi citra inputan akan dihasilkan sebuah angka yang merupakan hasil konvolusi dan membentuk matriks output tertentu (activation map).

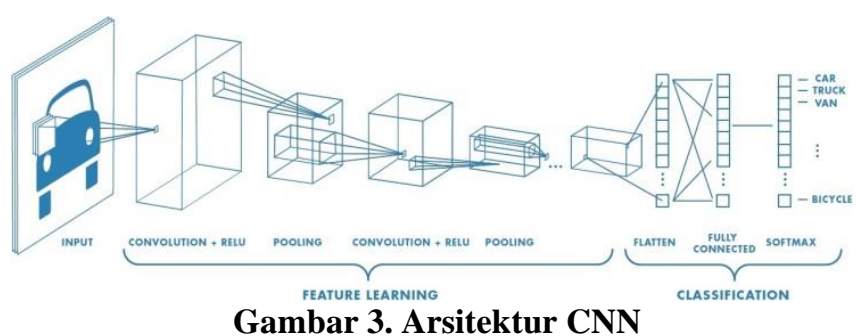

ReLu atau Rectified Linear Unit merupakan salah satu activation function yang membuat pembatas pada bilangan nol artinya apabila $\mathrm{x} \leq 0$ maka $\mathrm{x}=0$ dan apabila $\mathrm{x}>0$ maka $\mathrm{x}=\mathrm{x}$. Hal ini dilakukan untuk mengindari neuron mati selama backpropagation berlangsung. Gambar 4 merupakan gambaran mengenai Pooling. Pada pooling layer dilakukan proses pooling untuk memgurangi atau mereduksi dimensi inputan dengan melakukan operasi down-sampling. Hal ini dilakukan untuk mempermudah dan mempercepat komputasi selama proses pada CNN berjalan dan juga mengatasi overfitting. Metode pooling yang paling umum yaitu max pooling dengan memilih nilai terbesar pada daerah tertentu.

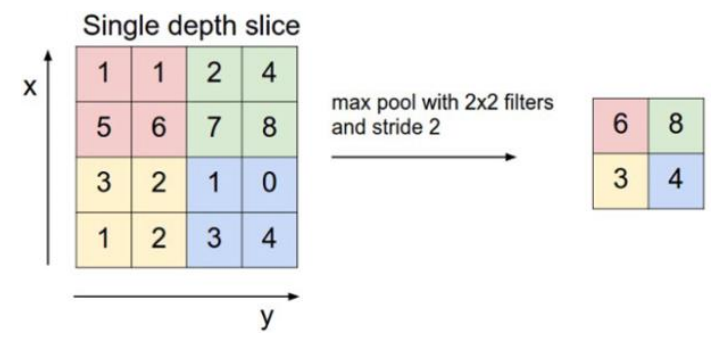

Gambar 4. Pooling (Max Pooling)

Tahap klasifikasi ini memiliki fokus utamanya yaitu mengklasifikasikan setiap neuron yang telah melewati tahap ektraksi fitur. Pada tahap klasifikasi ini terdiri dari Flatten, Fully-connected dan softmax. Flatten berfungsi untuk melakukan reshape atau membentuk ulang fitur-fitur agar menjadi sebuah vektor yang dapat digunakan sebagai input Fully-conneted. Fully-connecged akan bertugas melakukan perhitungan skor kelas seperti pada jaringan saraf tiruan umumnya. Softmax berfungsi untuk melakukan perhitungan probabilitas dari setiap nilai hasil untuk melakukan penentuan kelas target dari input yang diterima. Pada CNN terdapat fungsi loss yang dapat diatur dan dipilih sesuai keinginan dan kasus yang diteliti. Fungsi loss adalah sebuah fungsi objektif yang digunakan untuk mengukur performa karakteristik kualitas dalam pencapaian target tertentu pada proses CNN.

\subsection{Penelitian Terdahulu}

Pada penelitian milik Luján-García et al (2020) yang berjudul "A Transfer Learning Method for Pneumonia Classification and Visualization", telah dilakukan penelitian penggunaan dan pengimplementasian metode Transfer Learning yang digunakan untuk klasifikasi penyakit Pneumonia. Pada penelitian tersebut, tujuannya yaitu 
membuat tools otomatis untuk melakukan klasifikasi pada penyakit dada seperti Pneumonia dan juga membantu proses diagnosa pasien. Dataset Pneumonia yang digunakan berjumlah 5856 data gambar yang sudah diberikan label sesuai dengan nama penyakitnya (3883 Pneumonia dan sisanya normal).

Beban pretrained atau pretrained weight menggunakan weight pelatihan imagenet yang umum digunakan pada pembuatan model dengan menerapakan metode Transfer Learning. Pada penelitian tersebut, peneliti melakukan modifikasi pada exit flow dengan menambahkan beberapa layer tertentu. Layer-layer tersebut antara lain penghilangan layer logistic dan pooling, dan menambahkan Global Average Pooling Layer. Lalu pada bagian output menggunalan dua neuron dengan fungsi aktivasi sigmoid untuk melakukan prediksi terhadap citra input.

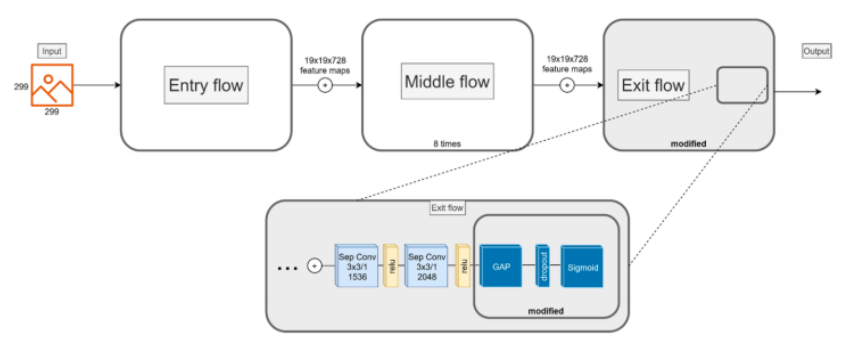

Gambar 5. Modifikasi Model

Data Augmentasi dilakukan dengan cara horizontal flipping, zoom range $\pm 10 \%$, dan rotasi gambar. Lalu melakukan seeting hyper parameter terhadap loss function, learning rate, optimize, epoch, dan batch size. Pada penelitian tersebut, dilakukan modifikasi pada bagian exit flow dari model Xception pre-trained seperti yang terlihat pada gambar 5 mengenai modifikasi dan penambahan layer. Berdasarkan penelitian tersebut, didapatkan bahwa model Xception yang telah dimodifikasi mendapatkan nilai presisi sebesar 0,843, nilai recall sebesar 0,992, nilai f1-score sebesar 0,912, dan presisi-recall AUC sebesar 0,973.

Pada penelitian lainnya, Wang et al. (2020) melakukan penelitian dengan artikel yang berjudul "An efficient mixture of deep and machine learning models for COVID19 diagnosis in chest X-ray images". Pada penelitian tersebut, Wang et al. menggunakan metode Transfer Learning pada lima pretrained Deep Learning model termasuk didalamnya yaitu model Xception. Model-model tersebut digunakan untuk melakukan klasifikasi dan alternatif dari metode diagnosis berdasarkan citra x-ray dada pasien.

Konsep penerapan dan implementasi metode Transfer Learning pada penelitian ini terdapat pada gambar 6 di bawah ini. Pada konsepnya model CNN akan menerima input dari gambar pada suatu dataset tertentu. CNN akan dilatih dengan menggunakan dataset tersebut dan didapati hasil knowledgenya/Tranfer Parameters pada umumnya akan berupa nilai weight atau nilai bobot. Kemudian
Transfer Parameters akan dilakukan pada model CNN yang baru, sehingga dilakukan dan diterapkan metode Transfer Learning yang sesungguhnya.

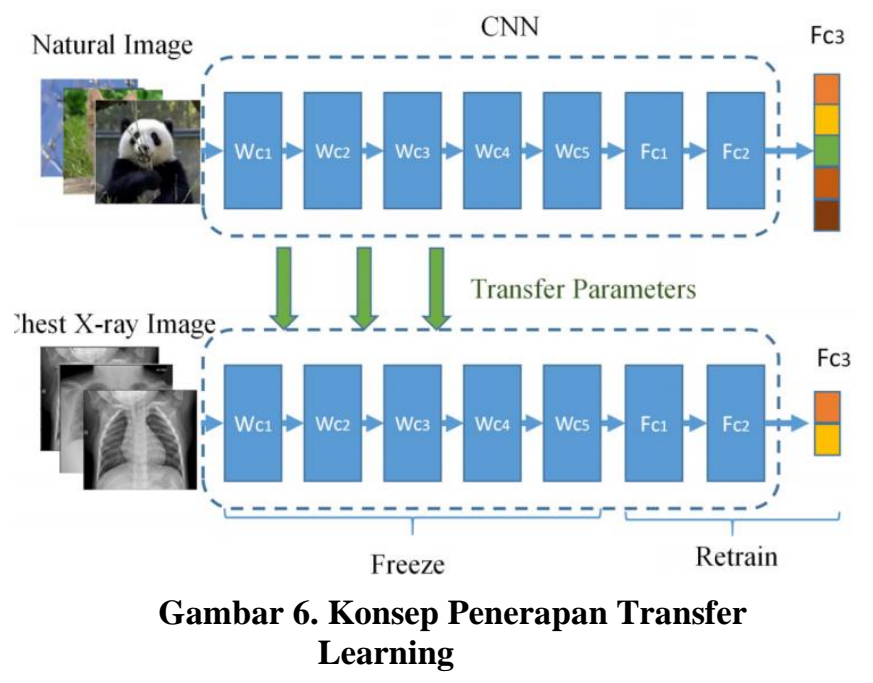

Pada model CNN baru dengan menerapkan metode Transfer Learning dilakukan fine-tuning dan penyesuaian workflow metode Transfer Learning. Dataset yang digunakan pada penelitian tersebut menggunakan dataset Chest X-ray image yang tentunya sesuai dengan permasalahan yang diteliti. Pada model CNN juga dilakukan freezing pada layer CNN dan juga melakukan retraining pada bagian exit flow/output model agar dapat melakukan klasifikasi sesuai dengan kasus yang sedang diteliti pada penelitian tersebut.

Terdapat preprocessing pada data input citra diubah ke dimensi $224 \times 224$ pixels. Lalu ada data augmentasi yang digunakan untuk menghindari masalah overfitting yang umumnya terjadi karena data citra training berjumlah sedikit. Dataset citra xray dada yang digunakan pada penelitian tersebut terdiri dari 537 data citra xray dada manusia normal dan 565 data citra xray dada pasien penderita COVID-19.

Berdasarkan artikel jurnal pada penelitian Wang et al., dituliskan bahwa Xception pretrained model dengan menggunakan Transfer Learning memiliki performa paling tinggi dibandingkan dengan model-model pretrained lainnya seperti VGG16, ResNet50, InceptionV3, dan DenseNet121.

Pada penelitian tersebut, akurasi model Xception dengan menggunakan metode Transfer Learning tertinggi didapatkan pada angka 96\%. Sedangkan pada tingkat sensitifitas paling tinggi mendapatkan nilai sebesar $94.16 \pm$ $0.60 \%$. Spesifisitas tertinggi pada nilai sebesar $99.17 \pm$ $0.29 \%$, nilai presisi tertinggi sebesar $98.97 \pm 0.36 \%$. Nilai F1 sebesar tertinggi $96.38 \pm 0.18 \%$, dan nilai AUC tertinggi sebesar $96.38 \pm 0.18 \%$.

\section{ANALISIS DAN PERANCANGAN SISTEM 3.1 Dataset}


Pada penelitian ini, dataset yang digunakan adalah dataset yang dimiliki oleh Tawsifur Rahman. Dataset ini dapat diakses secara gratis melalui link Kaggle https://www.kaggle.com/tawsifurrahman/covid19-

radiography-database. Pada dataset tersebut terdapat 3616 citra x-ray dada pasien penderita COVID-19, citra x-ray dada manusia normal, citra $\mathrm{x}$-ray dada pasien penderita Lung Opacity (infeksi paru-paru non-COVID) dan 1345 citra $\mathrm{X}$-ray dada pasien penderita Pneumonia.

Data-data citra $\mathrm{x}$-ray dada manusia yang akan digunakan hanya berfokus pada citra $\mathrm{x}$-ray dada pasien penderita COVID-19 dan citra $\mathrm{x}$-ray dada pasien penderita Pneumonia. Data-data citra x-ray dada pasien pada dataset dengan label Pneumonia dan COVID-19 saja yang digunakan pada penelitian ini. Hal ini dilakukan karena data-data citra tersebutlah yang relevan dengan penelitian ini.

Pada data-data citra x-ray dada pasien Pneumonia dan COVID-19 tidak memiliki perbedaan yang besar jika dilihat oleh orang-orang yang kurang memahami dunia medis dan radiologis. Namun pada citra-citra Pneumonia dan COVID19 memliki ciri yang masih dapat diperhatikan. Berikut ini adalah contoh gambar citra x-ray dada pasien penderita COVID-19 dan citra $\mathrm{x}$-ray dada manusia normal.

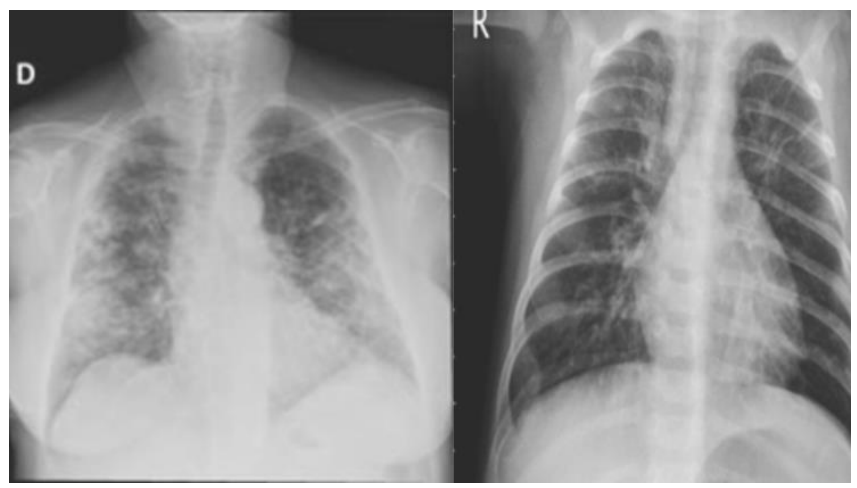

Gambar 7. COVID-19 (kiri) dan Pneumonia (kanan)

\subsection{Xception Model}

Arsitektur model yang digunakan dalam penelitian ini yaitu arsitektur Xception model sebagai model arsitektur dasar. Xception model menggunakan metode Depthwise Separable Convolution yang sudah dimodifikasi. Hal tersebut menjadikan Xception model memliki performa yang lebih baik daripada Inception-V3 yang menjadi Runner Up pada ILSVRC 2015 (Tsang, 2018).

Terdapat 3 tahap utama pada Xception model yaitu Entry Flow, Middle Flow, dan Exit Flow. Pada Entry Flow, input layer Xception model akan menerima inputan yang berupa citra 229 x 229 x 3. Xception Model menggunakan metode Separable Convolution yang merupakan modifikasi dari metode Depthwise Seperable Convolution. Fungsi aktivasi untuk setiap layer konvolusi dan fully connected adalah ReLU. Pada tahap terakhir akan dilakukan metode Logistic Regression. Gambar 8 merupakan arsitektur detail dari Xception model yang akan digunakan.
Pada bagian exit flow model Xception akan dilakukan modifikasi untuk menerapkan dan mengimplementasikan metode Transfer Learning pada model Xception. Modifikasi tersebut dilakukan dengan cara membuat custom head model dengan cara menghilangkan head model default dari Xception model dan menggantinya dengan custom head model. Hal ini dilakukan untuk melakukan Fine Tuning pada model pretrained Xception.

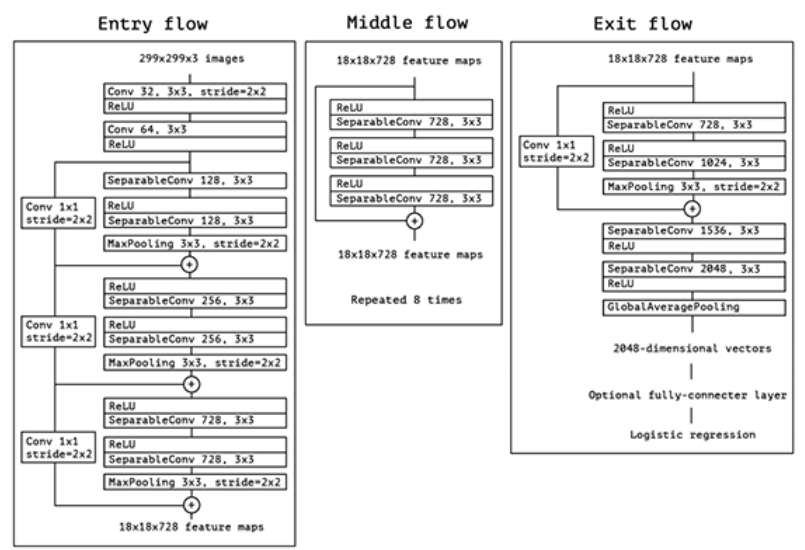

\section{Gambar 8. Arsitektur Xception}

\subsection{Transfer Learning Xception Model}

Konsep training model implementasi Transfer Learning pada penelitian ini dapat dilihat pada gambar 9. Model pretrained pada penelitian ini yaitu Xception model yang mendapat nilai beban atau nilai weight berasal dari pelatihan menggunakan imageNet dataset sebagai dataset trainingnya. Setelah model pre-trained tersebut dilatih menggunakan dataset imageNet maka akan didapatkan knowledge yang biasanya tersimpan dalam bentuk weight. Knowlegde tersebut akan dimasukkan pada model Xception yang digunakan pada penelitian ini untuk membantu memecahkan masalah klasifikasi COVID-19 dan Pneumonia.

Model Xception yang baru ini akan dilatih dengan menggunakan dataset COVID-19 dan Pneumonia sebagai input data bagi pelatihan. Hal ini dilakukan untuk menyelesaikan permasalahan pada penelitian ini dengan menggunakan metode Transfer Learning menggunakan nilai beban atau nilai weight yang didapatkan dari imagenet model Xception pre-trained.

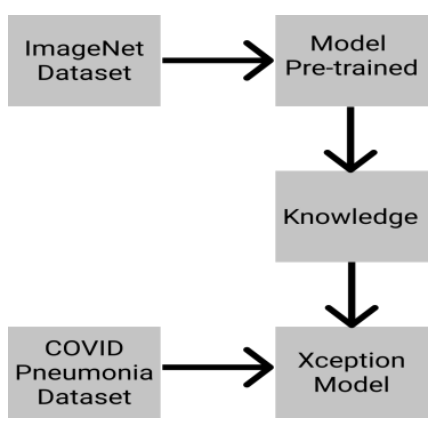




\section{Gambar 9. Transfer Learning Xception Model}

\subsection{Pra-proses Data}

Pada tahap training model akan diawali dengan pra-proses data atau data preprocessing akan dilakukan pemisahan data-data dari dataset yang sudah ditentukan. Pemisahan data train dan data test menggunakan dengan perbandingan data train dan data test adalah 8:2 yang nantinya akan digunakan pada tahap pelatihan model.

Pada tahap training ini dilakukan pengolahan pada data citra dengan cara data augmentasi. Data augmentasi adalah metode untuk memodifikasi dataset dengan tujuan memperbesar ukuran dataset agar akurasi dari suatu model bisa meningkat. Metode data augmentasi ini akan dijalankan dengan menggunakan Image Data Generator. Pada data augmentasi penelitian ini dilakukan beberapa perintah antara lain rescale, rotasi, shear range dan juga horizontal flip seperti pada tabel 1. Rescale digunakan untuk melakukan pembagian terhadap nilai RGB dari 0-255 dengan 255, sehingga didapatkan nilai RGB pada rentang antara $0-1$.

Tabel 1. Konfigurasi Praproses

\begin{tabular}{cc}
\hline Konfigurasi & Nilai \\
\hline Rescale & $1 . / 255$ \\
\hline Rotation Range & 20 \\
\hline Horizontal Flip & True \\
\hline Shear Range & 0.2 \\
\hline Fill Mode & Nearest \\
\hline
\end{tabular}

\subsection{Modifikasi Custom Head Model}

Pada pelatihan kedua model baik pada model Xception menggunakan Transfer Learning maupun model Xception tanpa menggunakan Transfer Learning akan dibuat sebuah modifikasi pada head model dengan cara menghilangkan head model default dari Xception model dan menggantinya dengan custom head model. Hal ini dilakukan untuk melakukan Fine Tuning pada model pretrained Xception. Adapun custom head model pada penelitian ini terdiri dari Global Average Pooling 2D dan output layer dengan fungsi aktivasi sigmoid. Tabel 2 berikut ini adalah tabel konfigurasi kode custom head model pada model Xception menggunakan metode Transfer Learning

Tabel 2. Konfigurasi Custom Head Model

\begin{tabular}{cc}
\hline Konfigurasi & Nilai \\
\hline Weights & imagenet \\
\hline Include Top & False \\
\hline Input Shape & $229,299,3$ \\
\hline
\end{tabular}

\begin{tabular}{cc}
\hline Head Model Input & Base Model Input \\
\hline Global Average Pooling2D & 1 Layer \\
\hline Output Layer & 1 Neuron \\
\hline Activation Function & Sigmoid \\
\hline
\end{tabular}

\subsection{Desain UI Web}

Pada tahap ini akan dilakukan pembuatan website yang akan menjadi aplikasi utama dan antarmuka (User Interface) pada penelitian ini. Proses pembuatan antarmuka website pendeteksian dan klasifikasi COVID-19 dan Pneumonia ini menggunakan HTML untuk dasar pembuatan website, CSS untuk mempercantik tampilan website, JS untuk beberapa interaksi pengguna pada tampilan front-end, Bootstrap untuk mempermudah pembuatan website dan framework Django untuk back-end.

Halaman-halaman website yang terdapat pada penelitian ini antara lain halaman home dan halaman hasil klasifikasi inputan citra. Berikut pada gambar 10 dan gambar 11 adalah mockup atau rancangan desain dari website yang akan dibuat pada penelitian ini.

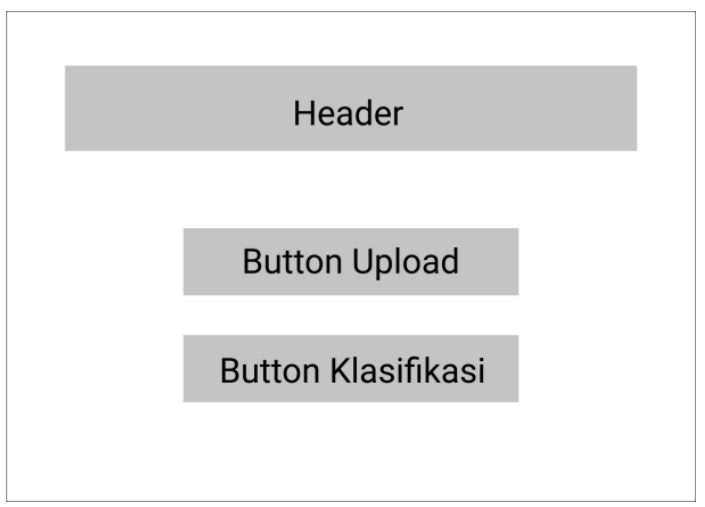

\section{Gambar 10. Mockup Halaman Home}

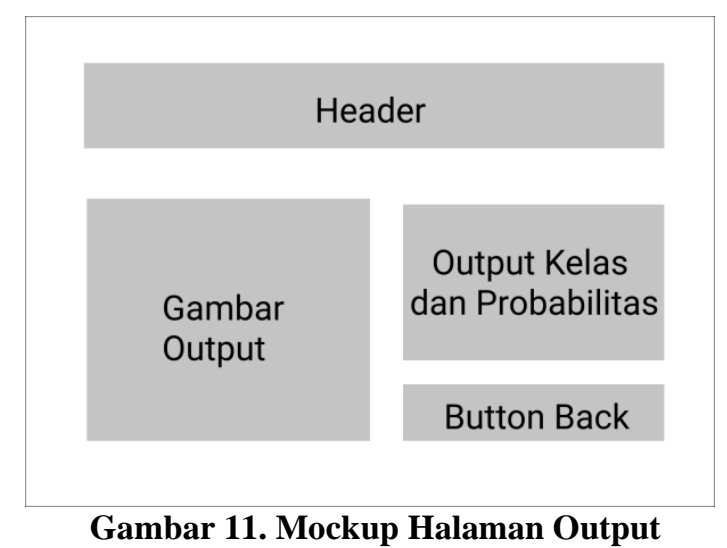

\subsection{Uji Coba Sistem}

Uji coba sistem dilakukan untuk mengetahui keoptimalan sistem yang dibuat. Tahap pengujian fungsionalitas sistem website diuji secara langsung dengan menjalankan aplikasi 
website yang sudah dibuat dengan memperhatikan berbagai kemungkinan yang dapat terjadi. Pengecekan kemungkinan yang dapat terjadi ini misalnya user belum mencantumkan gambar pada klasifikasi citra yang akan menyebabkan error. Pengujian model dilakukan dengan memperhatikan akurasi, sensitifitas dan spesifisitas menggunakan confusion matrix. Confusion matrix digunakan untuk melakukan evaluasi terhadap klasifikasi biner (klasifikasi 2 kelas). Pengujian model ini akan dilakukan pada Xception model yang digunakan. Gambar 12 adalah confusion matriks pada klasifikasi biner.

Pada confusion matriks terdapat True Class yang merupakan kondisi sebenarnya dan Predicted Class yang merupakan hasil prediksi atau hasil klasifikasi. True Positive (TP) merupakan kondisi dimana kelas positif dapat diprediksi sebagai kelas positif sesuai dengan keadaaan nyata. False Positive (FP) merupakan kodisi dimana kelas negative diprediksi sebagai kelas positif. False Negative merupakan kondisi dimana kelas positif diprediksi sebagai kelas negative. True Negative merupakan kondisi dimana kelas negative dapat terprediksi sebagai kelas negative sesuai keadaan nyata.

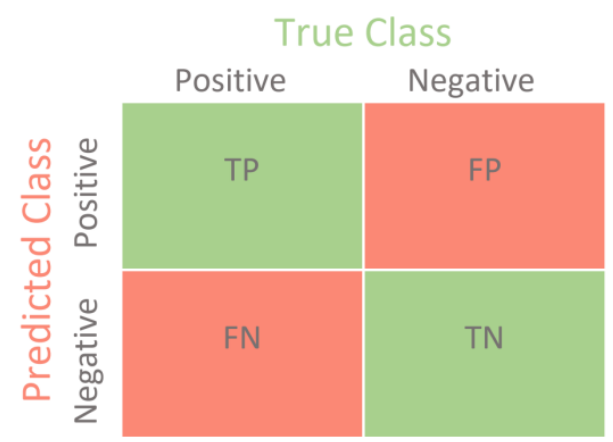

\section{Gambar 12. Confusion Matriks}

Berdasarkan data pada confusion matriks di atas maka bisa didapatkan akurasi, sensitifitas dan spesifisitas. Berikut adalah rumus akurasi berdasarkan confusion matriks.

$$
\text { Akurasi }=\frac{T P+T N}{T P+T N+F P+F N} \times 100 \%
$$

TP dan TN merupakan hasil prediksi yang sesuai dengan keadaan sesungguhnya sedangkan TP, TN, FP, dan FN merupakan jumlah klasifikasi yang dilakukan. Hasil akurasi akan semakin baik apabila FP dan FN mendekati nilai 0 dan berlaku untuk kebalikannya. Akurasi menunjukkan seberapa baik kinerja model dalam melakukan klasifikasi. Data pada confusion matriks juga dapat digunakan untuk melihat sensitifitas. Berikut adalah rumus sensitifitas berdasarkan confusion matiks.

$$
\text { Spesifisitas }=\frac{T N}{T N+F P} \times 100 \%
$$

Sensitifitas menunjukkan seberapa sensitif model yang dibuat dalam melakukan pendeteksian terhadap objek yang akan diklasifikasikan. Semakin tinggi sensitifitas maka semakin tinggi kemampuan model dalam melakukan deteksi dan pengenalan terhadap objek. Berikut ini merupakan rumus spesifisitas berdasarkan confusion matriks.

$$
\text { Spesifisitas }=\frac{T N}{T N+F P} \times 100 \%
$$

Spesifisitas menunjukkan tingkat ketepatan model dalam membedakan objek yang bukan objek kelas tertentu. Semakin tinggi persentase spesifisitas maka semakin tinggu pula tingkat kemampuan model dalam membedakan objek satu dengan objek lainnya. Tabel 3 berikut ini adalah confusion matriks untuk pengujian Xception model.

Tabel 3. Confusion Matriks Model

\begin{tabular}{|l|c|c|}
\hline \multirow{2}{*}{ Objek Sebenarnya } & \multicolumn{2}{c|}{ Hasil Prediksi } \\
\cline { 2 - 3 } & COVID-19 & Pneumonia \\
\hline COVID-19 & TP & FN \\
\hline Pneumonia & FP & TN \\
\hline
\end{tabular}

Di sisi lain, terdapat uji statistik dilakukan menggunakan pengujian T-Test yaitu Independent T-Test menggunakan software SPSS. Hal ini dilakukan untuk membandingkan Xception model menggunakan Transfer Learning dan Xception model tanpa Transfer Learning. Pengujian dilakukan pada hasil loss, accuracy, val_loss, dan val_accuracy.

Hipotesis awal (H0) adalah performa kedua model sama dan Transfer Learning tidak memiliki pengaruh terhadap performa dari model pretrained Xception dan H1, kedua performa model tidak sama dan Transfer Learning memiliki pengaruh terhadap performa dari model pretrained Xception. Jika hasil pengujian mendapatkan nilai Sig. (2tailed) di atas 0,05, maka dapat diartikan bahwa nilai data antara kedua model adalah homogen atau sama (gagal menolak H0). Namun jika nilai Sig. ((2-tailed) di bawah 0,05 maka ada perbedaan yang signifikan pada kedua model (berhasil menolak H0).

Pada independent t-test terdapat dua bentuk pengujian berdasarkan kesamaan varian (equal variances assumed dan equal variances not assumed). Pada kedua kelompok data dianggap memiliki kesamaan varian, perhitungan t-nya adalah sebagai berikut.

$$
t=\frac{M}{S E D}
$$

dimana

$M=$ Mean Difference

$\mathrm{SED}=$ Standard Error Difference (standar deviasi dari perbedaan antara rata-rata sampel)

\section{HASIL DAN PEMBAHASAN 4.1 Training Xception Model Transfer Learning}


Pada penelitian ini, Xception model menggunakan metode Transfer Learning dengan cara menggunakan knowledge yang didapatkan terhadap dataset imagenet. Knowledge atau pengetahuan tersebut berupa weight yang didapatkan dari proses training imagenet. Sebelum melakukan proses training, terdapat modifikasi pada model dasar Xception model yaitu dengan membuat dan menambahkan kepala model pada model dasar Xception model. Modifikasi tepatnya dilakukan pada Exit Flow Xception Model bagian output.

Kepala model akan menerima input dengan shape 299, 299, dan 3. Pada saat training kepala model, base model akan sengaja difreeze. Hal ini dilakukan supaya knowledge berupa beban atau weight tidak ikut terupdate dan berubah pada saat proses training model berjalan. Struktur kepala model terdiri dari input, GAP (Global Everage Pooling) 2 dimensi, dan output layer berjumlah 1 dengan fungsi aktivasi sigmoid. Fungsi aktivasi sigmoid dipilih pada penelitian ini karena fungsi sigmoid umum dan disarankan pada klasifikasi 2 kelas atau biasa disebut binary classification. Tabel 4 berikut adalah tabel konfigurasi pada saat training Model Xception Transfer Learning.

Tabel 4. Konfigurasi Training Xception Model Transfer Learning

\begin{tabular}{cc}
\hline Konfigurasi & Nilai \\
Weight & Imagenet \\
\hline Include Top & False \\
\hline Input Shape & $229 \times 299 \times 3$ \\
\hline Base Model Trainable & False \\
\hline Output Layer & 1 Neuron \\
\hline Learning Rate & 0,001 \\
\hline Beta1 & 0,9 \\
\hline Beta2 & 0,999 \\
\hline Activation Function & Sigmoid \\
\hline Loss Function & Binary Crossentropy \\
\hline Epoch & 20 \\
\hline Step Per Epoch & 10 \\
\hline
\end{tabular}

Pada proses training menggunakan Model Checkpoint agar menyimpan model dengan hasil terbaik selama proses training berjalan. Optimizer yang digunakan pada proses training yaitu optimizer Adam dengan epoch sebanyak 20, dan step per epoch sebanyak 10. Fine-tuning sudah dilakukan dengan menambahkan custom head model, sedangkan untuk melakukan dan mendapatkan hyper parameter akan menggunakan learning rate dan konfigurasi pada beta 1 dan beta 2 . Learning rate yang digunakan dalam pelatihan ini bernilai 0,001 . Pada beta 1 bernilai 0,9 dan pada beta 2 bernilai 0,999 . Setelah proses training selesai, didapati grafik proses training dengan informasi loss, valloss, accuracy, dan val-accuracy seperti pada gambar 13.

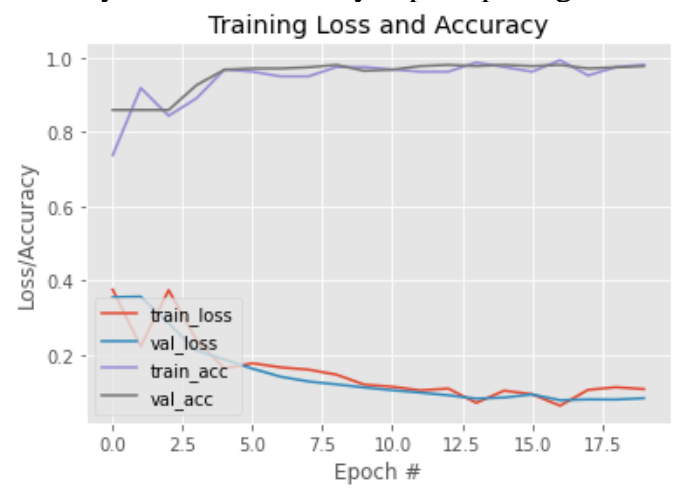

Gambar 13. Grafik Training Xception Model Transfer Learning

Setelah proses training selesai didapatkan nilai loss terkecil sebesar 0.0541, akurasi tertinggi sebesar 0.991, loss pada data validasi terkecil sebesar 0.0796, dan akurasi tertinggi pada data validasi sebesar 0.9808 . Model ini nantinya akan digunakan untuk melakukan klasifikasi image Pneumonia dan COVID-19.

\subsection{Training Xception Model Tanpa Transfer Learning}

Proses training pada Xception model tanpa Transfer Learning sedikit berbeda dengan Xception model dengan menggunakan Transfer Learning. Apabila Xception model menggunakan metode Transfer Learning, proses training berlangsung dengan cara menggunakan knowledge yang didapatkan terhadap dataset imagenet. Di sisi lain, proses training pada Xception model tanpa Transfer Learning dilakukan tanpa menggunakan knowledge berupa beban atau weight pada imagenet. Hal ini dilakukan dengan memberikan nilai inisialisasi beban/weight berangka random pada awal proses training.

Tabel 5. Konfigurasi Training Xception Model Tanpa Transfer Learning

\begin{tabular}{cc}
\hline Konfigurasi & Nilai \\
\hline Weight & None \\
\hline Include Top & False \\
\hline Input Shape & $229 \times 299 \times 3$ \\
\hline Base Model Trainable & True \\
\hline Output Layer & 1 Neuron \\
\hline Learning Rate & 0,001 \\
\hline Beta1 & 0,9 \\
\hline
\end{tabular}




\begin{tabular}{cc}
\hline Beta2 & 0,999 \\
\hline Activation Function & Sigmoid \\
\hline Loss Function & $\begin{array}{c}\text { Binary } \\
\text { Crossentropy }\end{array}$ \\
\hline Epoch & 20 \\
\hline Step Per Epoch & 10 \\
\hline
\end{tabular}

Pada proses training menggunakan Model Checkpoint agar menyimpan model dengan hasil terbaik selama proses training berjalan. Model Xception tanpa metode Transfer Learning ini tidak akan difreeze seperti yang dilakukan pada Xception model dengan Transfer Learning. Hal ini dilakukan supaya nilai beban/weight pada Xception model tanpa Transfer Learning dapat terus terupdate dan bisa mendapatkan nilai beban/weight yang paling baik pada saat proses training selesai. Cara melakukan freeze pada saat pelatihan yaitu dengan cara melakukan enable pada trainable base model sehingga valuenya bersifat True.

Fine-tuning sudah dilakukan dengan menambahkan custom head model, sedangkan untuk melakukan dan mendapatkan hyper parameter akan menggunakan learning rate dan konfigurasi pada beta1 dan beta 2 . Learning rate yang digunakan dalam pelatihan ini bernilai 0,001. Optimizer yang digunakan pada proses training yaitu optimizer Adam dengan epoch sebanyak 20, dan step per epoch sebanyak 10. Setelah proses training selesai, didapati grafik proses training dengan informasi loss, val-loss, accuracy, dan valaccuracy seperti pada gambar 14 .

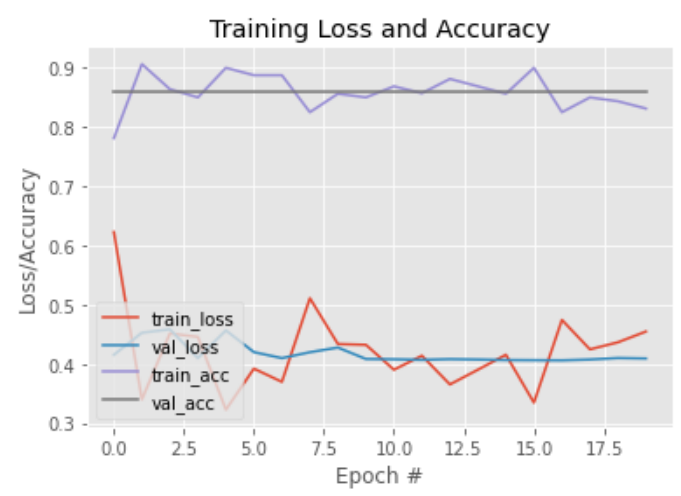

\section{Gambar 14. Grafik Training Xception Model Tanpa Transfer Learning}

Setelah proses training selesai didapatkan nilai loss terkecil sebesar 0.3652, akurasi tertinggi sebesar 0.9062, loss terkecil pada data validasi sebesar 0.463 , dan akurasi pada data validasi sebesar 0.8594. Model ini nantinya akan digunakan untuk melakukan klasifikasi image Pneumonia dan COVID-19.

\subsection{Website}

Pada saat pengguna pertama kali menggunakan aplikasi website ini, pengguna akan dapat melihat halaman awal atau halaman home seperti pada gambar 15. Pada halaman ini, pengguna akan diminta untuk memilih gambar atau citra yang akan diupload dari perangkat pengguna untuk melakukan klasifikasi. Gambar akan disave ke dalam folder images dan juga ke database yang telah disiapkan oleh framework Django dengan menggunakan model pada Django. Database yang digunakan pada aplikasi Django ini yaitu database PostgreSQL. Setelah gambar berhasil disave maka model akan mengklasifikasikan gambar atau citra inputan ke dalam kelas COVID-19 atau Pneumonia. Proses klasifikasi tersebut akan menggunakan model yang telah dilatih pada penelitian ini dengan menggunakan gambar $\mathrm{x}$ ray dada pasien Pneumonia dan COVID-19.

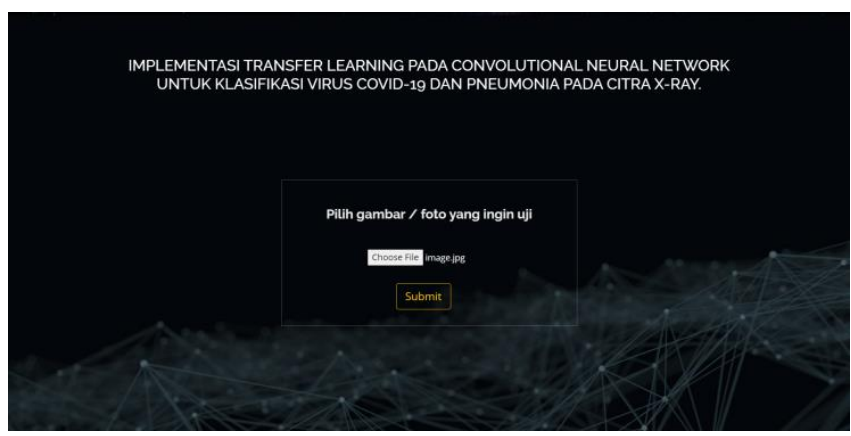

Gambar 15. Halaman Home

Setelah melalui tahap klasifikasi maka akan didapatkan output class dan juga probabilitas (tingkat kepercayaan) dari output class tersebut. Setelah melalui proses tersebut maka user akan diarahkan ke halaman output. Halaman output sendiri memiliki tampilan seperti pada gambar 16. Pada halaman ini akan ditampilkan informasi mengenai hasil klasifikasi berdasarkan gambar input. Informasi tersebut antara lain gambar atau citra input, hasil output class, dan juga nilai probabilitas atau tingkat kepercayaan.

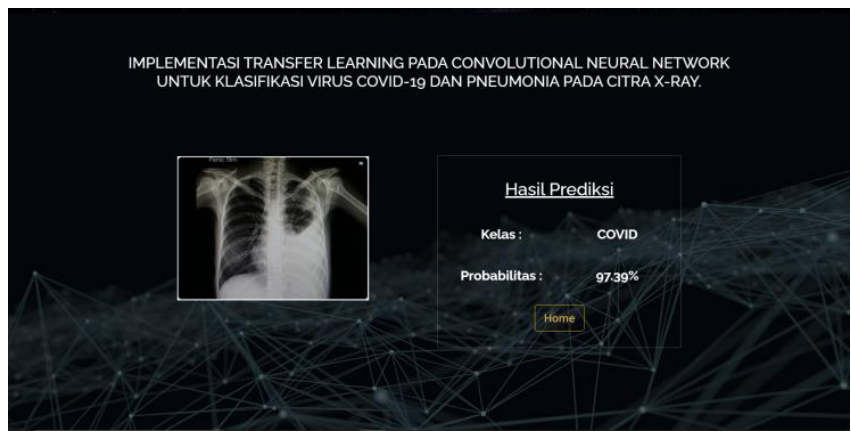

Gambar 16. Halaman Output

Fungsionalitas back-end menggunakan framework website Django dapat berjalan dengan baik pada saat dilakukan testing. Gambar X-ray dada pasien akan disave pada database PostgreSQL dengan menggunakan perintah pada Django framework. Model Machine Learning yang sudah dilatih dapat diintegrasikan dan digunakan dengan baik untuk keperluan klasifikasi input dan berhasil mendapatkan 
output sesuai dengan output model. Pada bagian halaman output, output dari model klasifikasi yang sudah dilatih sebelumnya dapat ditampilkan dengan baik pada halaman output berupa kelas dan juga nilai probabilitas output model.

\subsection{Evaluasi Xception Model}

Evaluasi Xception model berfokus hanya pada kemampuan sistem pendeteksian deteksi masker pada wajah manusia menggunakan model Xception yang telah dilatih. Eksperimen telah dilakukan dengan juga uji statistik dan confusion matriks. Pada pengujian statistik akan digunakan metode uji statistic menggunakan uji T-tes.

Pada eksperimen untuk mendapatkan confusion matriks Xception model dengan ataupun tanpa Transfer Learning akan menggunakan gambar uji. Gambar uji ini terdiri dari 20 gambar Pneumonia dan 20 gambar COVID-19 yang berasal dari dataset pada dataset training. Gambar Pneumonia sebanyak 20 gambar diambil secara acak dari folder dataset citra kelas Pneumonia. Di sisi lain, diambil juga 20 gambar citra COVID-19 yang diambil secara acak dari folder pada dataset citra kelas COVID-19. Setelah ke 20 masing-masing citra secara acak dari dataset yang sudah diambil tersebut akan menjadi input untuk masing-masing model Xception dengan Transfer Learnning dan juga model Xception tanpa menggunakan Transfer Learning.

Setelah proses klasifikasi untuk masing-masing 20 data citra Pneumonia dan COVID-19 berhasil dilakukan dengan baik menggunakan kedua model tersebut. Data output dan hasil klasifikasi akan direcord dan dimasukkan ke dalam confusion matrix untuk kembali dianalisa dan mendapatkan data-data mengenai performa masing-masing model seperti akurasi model, tingkat sensitifitas model, dan besar spesifisitas model.

\subsubsection{Evaluasi Xception Model Transfer Learning}

Evaluasi Xception model dengan menggunakan metode Transfer Leaning untuk melakukan klasifikasi terhadap gambar atau citra input ke dalam suatu kelas. Percobaan ini dilakukan dengan menggunakan 20 citra Pneumonia dan 20 Citra COVID-19. Berdasarkan eksperimen yang telah dilakukan maka didapati confusion matriks seperti pada tabel 6 di bawah ini.

Tabel 6. Confusion Matriks Model Xception Transfer Learning

\begin{tabular}{|l|c|c|}
\hline \multirow{2}{*}{ Objek Sebenarnya } & \multicolumn{2}{|c|}{ Hasil Prediksi } \\
\cline { 2 - 3 } & COVID-19 & Pneumonia \\
\hline COVID-19 & 20 & 0 \\
\hline Pneumonia & 1 & 19 \\
\hline
\end{tabular}

Berdasarkan tabel 6 di atas, didapati bahwa pada kondisi pertama ini mendapatkan tingkat akurasi sebesar 97,5\%, sensitifitas sebesar 100\% dan spesifisitas sebesar 95\%.

\subsubsection{Evaluasi Xception Model Tanpa Transfer Learning}

Evaluasi Xception model tanpa menggunakan metode Transfer Leaning untuk melakukan klasifikasi terhadap gambar atau citra input ke dalam suatu kelas. Percobaan ini dilakukan dengan menggunakan 20 citra Pneumonia dan 20 Citra COVID-19. Berdasarkan eksperimen yang telah dilakukan maka didapati confusion matriks seperti pada tabel 7 di bawah ini.

Tabel 7. Confusion Matriks Model Xception Tanpa Transfer Learning

\begin{tabular}{|l|c|c|}
\hline \multirow{2}{*}{ Objek Sebenarnya } & \multicolumn{2}{|c|}{ Hasil Prediksi } \\
\cline { 2 - 3 } & COVID-19 & Pneumonia \\
\hline COVID-19 & 20 & 0 \\
\hline Pneumonia & 20 & 0 \\
\hline
\end{tabular}

Berdasarkan tabel 7 di atas, didapati bahwa pada kondisi pertama ini mendapatkan tingkat akurasi sebesar 50\%, sensitifitas sebesar $100 \%$ dan spesifisitas sebesar $0 \%$.

\subsubsection{Uji T-test Xception Model}

Pengujian T-Test dilakukan untuk membandingkan performa pada Xception model yang menggunakan metode Transfer Learning dengan Xception model tanpa metode Transfer Learning. Hipotesis awal (H0) adalah performa kedua model sama dan Transfer Learning tidak memiliki pengaruh terhadap performa dari model pretrained Xception dan H1, performa kedua model tidak sama dan Transfer Learning memiliki pengaruh terhadap performa dari model pretrained Xception.

Hipotesis di atas termasuk ke dalam jenis hipotesis tak terarah yang termasuk ke dalam golongan hipotesis tak teararah komparatif. Hipotesis komparatif merupakan pengujian hipotesis untuk mendapatkan informasi mengenai perbedaan antara kedua objek. Dalam pengujian hipotesis tidak terarah menggunakan metode pengujian 2-tailed. Pada pengujian penelitian ini, akan melihat dan berfokus pada nilai $\operatorname{Sig}(2$-tailed) yang menunjukkan nilai signifikan dengan metode pengujian 2-tailed. Pada tabel 8 berikut ini merupakan hasil uji T-Test pada data loss train, akurasi pada train, loss data validasi, dan akurasi data validasi.

Tabel 8. Hasil Uji T-Test

\begin{tabular}{cc}
\hline T-test & Sig(2-tailed) \\
\hline Loss Data Train & $1.4731 \mathrm{E}-11$ \\
\hline Akurasi Data Train & $5.086 \mathrm{E}-23$ \\
\hline Loss Data Validasi & $5.4076 \mathrm{E}-30$ \\
\hline Akurasi Data Validasi & $3.5843 \mathrm{E}-12$ \\
\hline
\end{tabular}

Pada tabel 8 menunjukkan nilai Sig. (2-tailed) 1.4731E-11 pada loss data train dan pada tabel 8 menunjukkan nilai 
Sig. (2-tailed) 5.086E-23 pada akurasi data train sehingga pada loss dan akurasi pada data train berhasil tolak H0. Maka dapat disimpulkan bahwa performa kedua model tidak sama dan Transfer Learning memiliki pengaruh terhadap performa dari model pretrained Xception. Hal ini berarti bahwa penerapan metode Transfer Learning memiliki pengaruh yang positif terhadap performa dari model pretrained Xception dan menjadikan model pretrained Xception yang menerapkan metode Transfer Learning memiliki performa yang lebih baik jika dibandingkan dengan model Xception tanpa menggunakan Transfer Learning.

Pada tabel 8 menunjukkan nilai Sig. (2-tailed) 5.4076E-30 pada loss data validasi dan pada tabel 8 menunjukkan nilai Sig. (2-tailed) 3.5843E-12 pada akurasi data validasi sehingga pada loss dan akurasi pada data validasi berhasil tolak H0. Maka dapat disimpulkan bahwa performa kedua model tidak sama dan Transfer Learning memiliki pengaruh terhadap performa dari model pretrained Xception. Hal ini berarti bahwa penerapan metode Transfer Learning memiliki pengaruh yang positif terhadap performa dari model pretrained Xception dan menjadikan model pretrained Xception yang menerapkan metode Transfer Learning memiliki performa yang lebih baik jika dibandingkan dengan model Xception tanpa menggunakan Transfer Learning.

\subsection{Eksperimen Model Tanpa Transfer Learning}

Eksperimen dilakukan untuk melakukan pengujian ulang terhadap dampak dan efek dari metode Transfer Learning pada model pre-trained. Hal ini dilakukan karena model Xception pre-trained tanpa menggunakan Transfer Learning memiliki keanehan dimana akurasi data train dan akurasi data validasi pada saat training model berbeda dengan akurasi model yang didapatkan pada saat testing kembali model dengan cara melakukan load model lalu melakukan klasifikasi dengan menginputkan citra ke dalam model Xception tanpa metode Transfer Learning.

Terdapat beberapa skenario eksperimen yang dilakukan pada percobaan training model tanpa Transfer Learning. Pada eksperimen pertama dilakukan dengan melihat dan memperhatikan performa model Xception pre-trained tanpa menggunakan metode Transfer Learning dengan melakukan enable training pada semua layers pada base model (for layer in base_model.layers: layer.trainable $=$ True).

Pada skenario eksperimen yang kedua akan melihat performa model Xception pre-trained yang berbeda dengan eksperimen-eksperimen sebelumnya. Skenario eksperimen yang kedua yaitu dengan melakukan enable training pada base model Xception non Transfer Learning (base_model.trainable $=$ True) dan melakukan disable training pada custom head model ( $\mathrm{x}=$ base_model(inputs, training $=$ False $)$ ).

Di sisi lain, pada skenario eksperimen yang ketiga dilakukan dengan cara melakukan enable training pada base model (base_model.trainable $=$ True) dan juga enable

training pada custom head model $(\mathrm{x}=$ base_model(inputs, training=True)). Pada skenario eksperimen yang keempat dilakukan dengan cara melakukan enable training pada layer-layer base model Xception pre-trained non Transfer Learning dan tidak menggunakan model checkpoint yang digunakan untuk melakukan save hanya pada model yang memiliki performa terbaik. Hal ini dilakukan karena ada kemungkinan pada epoch tertentu dimana performa model menjadi yang terbaik akan disave, sedangkan pada epochepoch selanjutnya dimana seharusnya model Xception non Transfer Learning masih melakukan update bobot dan juga perbaikan nilai bobot tidak akan tersave pada model yang disimpan.

Terdapat 2 eksperimen tambahan dimana tidak menggunakan model Xception pre-trained lagi untuk mengimplementasikan non Transfer Learning. Kedua model tersebut adalah model Resnet50 pre-trained dan model VGG16 pre-trained. Kedua model ini dipilih karena kedua model ini memiliki performa klasifikasi yang hampir mirip dengan model Xception pre-trained. Model Resnet50 pretrained dan model VGG16 pre-trained terdapat di dua jurnal penelitian terdahulu dan terbukti dapat digunakan untuk klasifikasi penyakit pernafasan seperti COVID-19 dan Pneumonia berdasarkan citra inputan berupa citra hasil $\mathrm{x}$ ray dada pasien. Pada kedua jurnal tersebut, model Resnet50 dan VGG16 memiliki performa yang tinggi dan mirip dengan performa yang dimiliki oleh Xception model.

\subsubsection{Eksperimen Model Xception Tanpa Transfer Learning}

Pada eksperimen model Xception tanpa menggunakan Transfer Learning ini, akan dilakukan dilakukan percobaan dengan menerapkan keempat konfigurasi pada model Xception non Transfer Learning. Konfigurasi keempat perbedaan tersebut dapat dilihat pada tabel 9 di bawah ini.

Tabel 9. Konfigurasi Pelatihan Model Xception Tanpa Transfer Learning

\begin{tabular}{ccccc}
\hline Konfigurasi & $\begin{array}{c}\text { Eksperimen } \\
\text { ke-1 }\end{array}$ & $\begin{array}{c}\text { Eksperimen } \\
\text { ke-2 }\end{array}$ & $\begin{array}{c}\text { Eksperimen } \\
\text { ke-3 }\end{array}$ & $\begin{array}{c}\text { Eksperimen } \\
\text { ke-4 }\end{array}$ \\
\hline Weight & None & None & None & None \\
\hline Include Top & False & False & False & False \\
\hline Input Shape & $229 \times 299 \times 3$ & $229 \times 299 \times 3$ & $229 \times 299 \times 3$ & $229 \times 299 \times 3$ \\
\hline $\begin{array}{c}\text { Base Model } \\
\text { Trainable }\end{array}$ & - & True & True & - \\
\hline $\begin{array}{c}\text { Base Model } \\
\text { Layers Trainable }\end{array}$ & True & - & - & True \\
\hline $\begin{array}{c}\text { Custom Head } \\
\text { Model Trainable }\end{array}$ & - & False & True & True \\
\hline $\begin{array}{c}\text { Output Layer } \\
\text { Learning Rate }\end{array}$ & 1 Neuron & 1 Neuron & 1 Neuron & 1 Neuron \\
\hline Beta1 & 0,001 & 0,001 & 0,001 & 0,001 \\
\hline Beta2 & 0,999 & 0,999 & 0,9 & 0,9 \\
\hline $\begin{array}{c}\text { Activation } \\
\text { Function }\end{array}$ & Sigmoid & Sigmoid & Sigmoid & Sigmoid \\
\hline Loss Function & $\begin{array}{c}\text { Binary } \\
\text { Crossentropy }\end{array}$ & $\begin{array}{c}\text { Binary } \\
\text { Crossentropy }\end{array}$ & $\begin{array}{c}\text { Binary } \\
\text { Crossentropy }\end{array}$ & $\begin{array}{c}\text { Binary } \\
\text { Crossentropy }\end{array}$ \\
\hline Epoch & 20 & 20 & 20 & 20 \\
\hline Step Per Epoch & 10 & 10 & 10 & 10 \\
\hline
\end{tabular}


Pada pelatihan model Xception tanpa menggunakan metode Transfer Learning dengan skenario percobaan yang pertama, didapati hasil pelatihan berupa akurasi data train, akurasi data validasi, loss data train, dan juga loss data validasi. Didapati akurasi data train tertinggi sebesar 0.93, akurasi pada data validasi tertinggi sebesar 0.859 , loss data train terkecil bernilai 0.39 , dan loss data validasi terkecil bernilai 0.53 seperti pada gambar 17 di bawah ini.

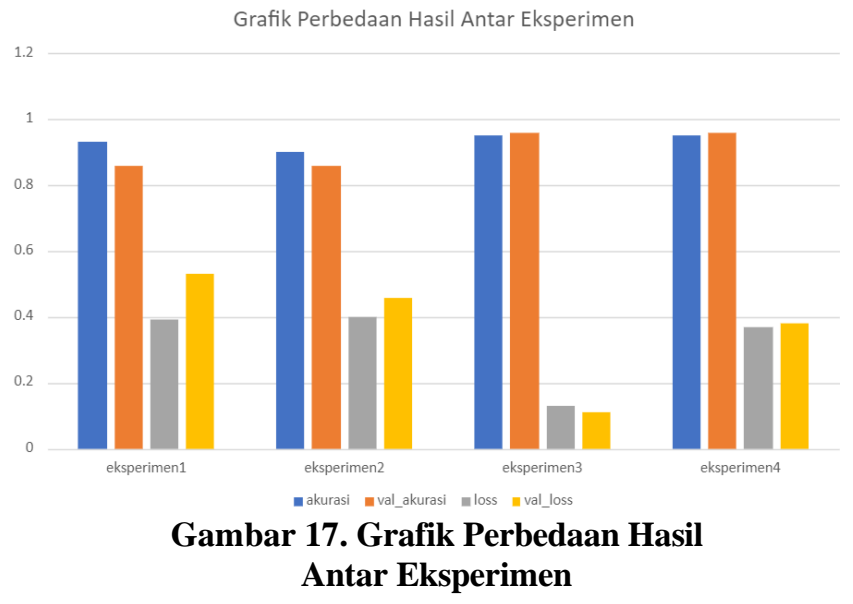

Pada eksperimen model Xception tanpa menggunakan Transfer Learning yang kedua, akan dilakukan percobaan dengan cara melakukan enable training pada base model Xception non Transfer Learning (base_model.trainable = True) dan juga melakukan disable training pada custom head model $(\mathrm{x}=$ base_model(inputs, training=False $)$ ). Hal ini dilakukan untuk mengetahui dan melihat bagaimana performa model Xception tanpa metode Transfer Learning dengan percobaan seperti di atas. Pada eksperimen yang kedua ini akan dilakukan training model Xception dengan konfigurasi seperti pada tabel 9 kolom eksperimen ke-2.

Pada pelatihan model Xception tanpa menggunakan metode Transfer Learning dengan skenario percobaan yang kedua ini, didapati hasil pelatihan berupa akurasi data train, akurasi data validasi, loss data train, dan juga loss data validasi. Didapati akurasi data train tertinggi sebesar 0.90, akurasi pada data validasi tertinggi sebesar 0.859 , loss data train terkecil bernilai 0.401 , dan loss data validasi terkecil bernilai 0.458 seperti pada gambar 17 .

Pada eksperimen model Xception tanpa menggunakan Transfer Learning yang ketiga, akan dilakukan percobaan dengan cara melakukan enable training pada base model (base_model.trainable $=$ True) dan juga enable training pada custom head model $(\mathrm{x}=$ base_model(inputs, training=True)). Hal ini dilakukan untuk mengetahui dan melihat bagaimana performa model Xception tanpa metode Transfer Learning dengan percobaan seperti di atas. Pada eksperimen yang ketiga ini akan dilakukan training model Xception dengan konfigurasi seperti pada tabel 9 kolom eksperimen ke-3.
Pada pelatihan model Xception tanpa menggunakan metode Transfer Learning dengan skenario percobaan yang ketiga ini, didapati hasil pelatihan berupa akurasi data train, akurasi data validasi, loss data train, dan juga loss data validasi. Didapati akurasi data train tertinggi sebesar 0.95, akurasi pada data validasi tertinggi sebesar 0.96 , loss data train terkecil bernilai 0.13 , dan loss data validasi terkecil bernilai 0.11 seperti pada gambar $17 \mathrm{di}$ atas.

Pada eksperimen model Xception tanpa menggunakan Transfer Learning yang keempa, akan dilakukan percobaan dengan cara melakukan enable training pada layer-layer base model Xception pre-trained non Transfer Learning dan tidak menggunakan model checkpoint yang digunakan untuk melakukan save hanya pada model yang memiliki performa terbaik.

Hal ini dilakukan karena ada kemungkinan pada epoch tertentu dimana performa model menjadi yang terbaik akan disave, sedangkan pada epoch-epoch selanjutnya dimana seharusnya model Xception non Transfer Learning masih melakukan update bobot dan juga perbaikan nilai bobot tidak akan tersave pada model yang disimpan. Hal ini dilakukan untuk mengetahui dan melihat bagaimana performa model Xception tanpa metode Transfer Learning dengan percobaan seperti di atas. Pada eksperimen yang keempat ini akan dilakukan training model Xception dengan konfigurasi seperti pada tabel 9 kolom eksperimen ke-4.

Pada pelatihan model Xception tanpa menggunakan metode Transfer Learning dengan skenario percobaan yang keempat ini, didapati hasil pelatihan berupa akurasi data train, akurasi data validasi, loss data train, dan juga loss data validasi. Didapati akurasi data train tertinggi sebesar 0.95, akurasi pada data validasi tertinggi sebesar 0.96, loss data train terkecil bernilai 0.37 , dan loss data validasi terkecil bernilai 0.38 seperti pada gambar 17 .

\subsubsection{Eksperimen Model Resnet50 dan VGG16 Tanpa Transfer Learning}

Pada eksperimen model Resnet50 dan VGG16 pre-trained tanpa menggunakan metode Transfer Learning ini akan dilakukan percobaan implementasi non Transfer Learning pada model Resnet50. Model ini dipilih karena model Resnet50 dan VGG16 ini memiliki performa klasifikasi yang hampir mirip dengan model Xception pre-trained dan model Resnet50 serta VGG16 pre-trained ini juga terdapat di dua jurnal penelitian terdahulu dan terbukti dapat digunakan untuk klasifikasi penyakit pernafasan seperti COVID-19 dan Pneumonia berdasarkan citra inputan berupa citra hasil x-ray dada pasien. Pada kedua jurnal tersebut, model Resnet50 dan VGG16 memiliki performa yang tinggi dan mirip dengan performa yang dimiliki oleh Xception model dalam hal klasifikasi inputan berupa citra.

Pada eksperimen model Resnet50 dan VGG16 tanpa menggunakan Transfer Learning dilakukan untuk mengetahui dan melihat bagaimana performa model Resnet50 dan VGg16 tanpa metode Transfer Learning jika 
dibandingkan dengan model Xception tanpa metode Transfer Learning dengan percobaan seperti di atas. Pada eksperimen ini akan dilakukan training pada model Resnet50 dan VGg16 dengan konfigurasi seperti pada tabel 10 di bawah ini.

\section{Tabel 10. Tabel Konfigurasi Pelatihan Model Resnet50 dan VGG 16 non Transfer Learning}

\begin{tabular}{ccc}
\hline Konfigurasi & Resnet50 & VGG16 \\
Weight & None & None \\
\hline Include Top & False & False \\
\hline Base Model Trainable & True & True \\
\hline Input Shape & $229 \times 299 \times 3$ & $229 \times 299 \times 3$ \\
\hline Output Layer & 1 Neuron & 1 Neuron \\
\hline Learning Rate & 0,001 & 0,001 \\
\hline Beta1 & 0,9 & 0,9 \\
\hline Beta2 & 0,999 & 0,999 \\
\hline Activation Function & Sigmoid & Sigmoid \\
\hline Loss Function & Binary Crossentropy & Binary Crossentropy \\
\hline Epoch & 20 & 20 \\
\hline Step Per Epoch & 10 & 10 \\
\hline & &
\end{tabular}

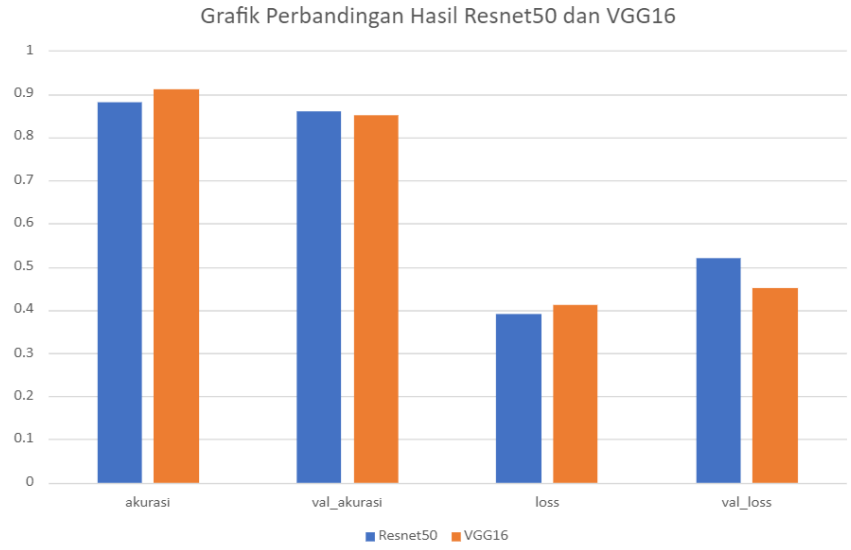

\section{Gambar 18. Grafik Perbedaan Hasil Resnet50 dan VGG16 Tanpa Transfer Learning}

Pada pelatihan model Resnet50 tanpa menggunakan metode Transfer Learning dengan skenario dan konfigurasi percobaan seperti pada tabel 10 di atas ini, didapati hasil pelatihan berupa akurasi data train, akurasi data validasi, loss data train, dan juga loss data validasi. Didapati akurasi data train tertinggi sebesar 0.88 , akurasi pada data validasi tertinggi sebesar 0.859, loss data train terkecil bernilai 0.39 , dan loss data validasi terkecil bernilai 0.52 seperti pada gambar 18 di atas.

Pada pelatihan model VGG16 tanpa menggunakan metode Transfer Learning dengan skenario dan konfigurasi percobaan seperti pada tabel 10 di atas ini, didapati hasil pelatihan berupa akurasi data train, akurasi data validasi, loss data train, dan juga loss data validasi. Didapati akurasi data train tertinggi sebesar 0.91 , akurasi pada data validasi tertinggi sebesar 0.85 , loss data train terkecil bernilai 0.41 , dan loss data validasi terkecil bernilai 0.45 seperti pada gambar 18 di atas.

\subsubsection{Hasil Eksperimen}

Terdapat 4 eksperimen Xception model tanpa menggunakan metode Transfer Learning dengan masing-masing perbedaan konfigurasinya antara lain konfigurasi pelatihan layer base model, pelatihan base model, pelatihan custom head model, dan pelatihan pada layer base model serta custom head model. Selain keempat percobaan menggunakan model Xception, terdapat 2 eksperimen yang menggunakan model Resnet50 dan VGG16 tanpa Transfer Learning dengan konfigurasi yang sama dengan Xception model tanpa menggunakan metode Transfer Learning.

Pada keempat eksperimen Xception model tanpa menggunakan metode Transfer Learning, didapati hasil bahwa keempat model tersebut memiliki akurasi diatas $85 \%$. Namun pada saat percobaan dilakukan untuk menguji performa masing-masing model dengan cara me-load model lalu melakukan klasifikasi dengan inputan citra $\mathrm{x}$-ray dada pasien dari data validasi, didapatkan bahwa keempat model memiliki performa yang sama dengan performa model Xception dengan konfigurasi pada subab 4.1.2 bahwa confusion matrix memiliki kemiripan dimana model tidak dapat mengenali Pneumonia.

Pada kedua eksperimen Resnet50 model dan VGG16 model tanpa menggunakan metode Transfer Learning, didapati hasil bahwa kedua model tersebut memiliki akurasi yang kurang lebih sama dengan keempat eksperimen sebelumnya dimana akurasi yang berhasil didapatkan bernilai diatas $85 \%$. Namun pada saat percobaan dilakukan untuk menguji performa masing-masing model dengan cara me-load model lalu melakukan klasifikasi dengan inputan citra $\mathrm{x}$-ray dada pasien dari data validasi, didapatkan bahwa kedua model tersebut (Resnet50 dan VGG16 model tanpa Transfer Learning) memiliki performa yang sama dengan performa model Xception dengan konfigurasi pada subab 4.1.2 bahwa confusion matrix memiliki kemiripan dimana model tidak dapat mengenali Pneumonia.

Keenam model di atas sama-sama memiliki kemiripan dalam confusion matrix seperti pada subab 4.3.1. Hal ini dapat diakibatkan oleh dua hal yaitu ukuran dataset dan jumlah epoch pelatihan serta adanya perbedaan jumlah dataset COVID-19 dan Pneumonia. Model Xception dengan menggunakan Transfer Learning menggunakan nilai beban atau weight yang merupakan knowledge transfer dari imagenet. Imagenet sendiri merupakan dataset yang terdiri lebih dari 1 juta gambar yang digunakan untuk pelatihan dan terdiri dari 1000 kelas. Knowledge transfer berupa weight didapatkan dari pelatihan terhadap dataset imagenet dan pastinya jumlah pelatihan dan epochnya memiliki jumlah beribu-ribu atau bahkan lebih. Jumlah dataset yang besar dan pelatihan yang banyak tersebut dapat menjadi salah satu faktor dimana Xception model dengan Transfer 
Learning menggunakan nilai weight imagenet memliki performa yang lebih baik daripada performa Xception, Resnet50, dan VGG16 tanpa menggunakan Transfer Learning dan dapat mengenali COVID-19 dan Pneumonia pada citra inputan $\mathrm{x}$-ray dada pasien dengan sangat baik.

Hal kedua yang bisa menjadi faktor Xception model menggunakan Transfer Learning memliki performa yang jauh lebih baik daripada model tanpa menggunakan metode Transfer Learning yaitu jumlah dataset yang digunakan pada penelitian ini. Jumlah data citra pada dataset imagenet terdiri dari 1,2 juta gambar. Dataset imagenet terdiri dari 1000 kelas dan masing-masing kelas memiliki 1200 gambar. Pada dataset imagenet, citra masing-masing kelas memiliki jumlah yang sama yaitu 1200 gambar. Hal ini bisa menjadi salah satu faktor yang mempengaruhi performa model Xception, Resnet50, dan VGG16 dimana dataset yang digunakan pada penelitian ini berjumlah 4961 citra secara keseluruhan. Dataset pada penelitian ini terdiri dari 3616 citra $\mathrm{x}$-ray dada pasien COVID-19 dan 1345 citra Xray dada pasien Pneumonia. Terdapat perbedaan yang cukup signifikan pada kedua dataset kelas COVID-19 dan Pneumonia dengan perbandingan rasio kurang lebih 3:1. Hal ini juga bisa menjadi salah satu faktor penting jauhnya performa antara model yang menggunakan metode Transfer Learning dengan model yang tidak menggunakan Transfer Learning

\subsection{Kesimpulan}

\section{KESIMPULAN DAN SARAN}

Penelitian tugas akhir yang berjudul "IMPLEMENTASI TRANSFER LEARNING PADA CNN UNTUK DIAGNOSIS COVID-19 DAN PNEUMONIA PADA CITRA X-RAY" sudah berjalan dengan baik. Berdasarkan penelitian yang telah dilakukan didapatkan simpulan sebagai berikut.

1. Machine Learning dapat digunakan untuk melakukan klasifikasi COVID-19 dan Pneumonia berdasarkan input cita $\mathrm{x}$-ray dada pasien dimana citra dari kedua penyakit tersebut sangat mirip dan hanya bisa dibaca oleh orang dengan pengetahuan medis.

2. Implementasi metode Transfer Learning memiliki pengaruh terhadap model Xception pre-trained yang dapat dilihat pada Uji T-test dimana performa kedua model tidak sama dan Transfer Learning memiliki pengaruh terhadap performa dari model pretrained Xception. Hal ini berarti bahwa penerapan metode Transfer Learning memiliki pengaruh yang positif terhadap performa dari model pretrained Xception dan menjadikan model pretrained Xception yang menerapkan metode Transfer Learning memiliki performa yang lebih baik jika dibandingkan dengan model Xception tanpa menggunakan Transfer Learning.

3. Model Xception, Resnet50, dan VGG16 pretrained tanpa menggunakan metode Transfer Learning memiliki akurasi data train dan data validasi yang baik namun pada saat klasifikasi dengan me-load model dan melakukan klasifikasi dengan menginputkan citra, akurasi dan performa yang didapatkan sama dengan model Xception tanpa metode Transfer Learning.

\subsection{Saran}

Berdasarkan kesimpulan yang sudah diperoleh, maka terdapat beberapa saran yang bisa dicoba untuk penelitianpenelitian selanjutnya yaitu sebagai berikut.

1. Memperbesar dataset baik pada dataset COVID-19 maupun pada dataset Pneumonia agar model dapat belajar lebih banyak ciri ataupun pola sehingga bisa mendapatkan model yang lebih baik.

2. Melakukan penelitian lebih lanjut mengenai penggunaan metode Transfer Learning maupun tanpa Transfer Learning.

3. Penelitian mengenai klasifikasi penyakit tidak hanya terbatas pada foto citra $\mathrm{x}$-ray dada pasien dengan posisi Posteroanterior.

\section{Daftar Pustaka}

Alodokter, 2021. Alodokter. [Online] Available at: https://www.alodokter.com/covid-19 [Accessed 22 Maret 2021].

Fahrani, M., 2020. Gala Media News. [Online] Available at: https://www.galamedianews.com/?arsip=246660\&j udul=dirilis-rumah-sakit-cina-mengejutkan-hasil$\mathrm{x}$-ray-paru-paru-penderita-virus-corona [Accessed 19 Maret 2021].

Handayani, D. et al., 2020. Penyakit Virus Corona 2019. JURNAL RESPIROLOGI INDONESIA, 4(2), pp.119-29.

Irawan, R., Reviono \& Harsini, 2019. Korelasi Kadar Copeptin dan Skor PSI dengan Waktu Terapi Sulih Antibiotik Intravena ke Oral dan Lama Rawat Pneumonia Komunitas. Jurnal Respirologi Indonesia, 39(1), pp.44-53.

Luján-García, J.E., Márquez, C.Y., Rey, Y.V. \& Nieto, O.C., 2020. A Transfer Learning Method for Pneumonia Classification and Visualization. applied sciences, 10(2908), pp.1-18.

Sena, S., 2017. Pengenalan Deep Learning Part 1 : Neural Network. [Online] Available at:
https://medium.com/@samuelsena/pengenalandeep-learning-8fbb7d8028ac [Accessed 15 Augustus 2020].

Tsang, S.H., 2018. towards data science. [Online] Available at: $\quad$ https://towardsdatascience.com/reviewxception-with-depthwise-separable-convolutionbetter-than-inception-v3-image-dc967dd42568 [Accessed 24 Maret 2021].

Wang, D. et al., 2020. An efficient mixture of deep and machine learning models for COVID-19 diagnosis in chest X-ray images. PLOS ONE, 15(11), pp.115.

Worldometer, 2021. Worldometer. [Online] Available at: https://www.worldometers.info/coronavirus/ [Accessed 19 Maret 2021]. 